\title{
Determination of Chemical Composition and Nutritive Value of Some Vegetables Leaves for Ruminant Animals
}

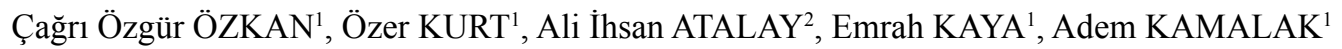

\begin{abstract}
The current experiment was carried out to determine the chemical composition and nutritive value of leaves of some vegetables for ruminant animals. The species significantly $(\mathrm{P}<0.001)$ affected the chemical composition of vegetable leaves. The dry matter (DM), crude ash (CA) crude protein (CP), neutral detergent fiber (NDF) and acid detergent fiber (ADF) of vegetables leaves varied between 8.29 and $20.89 \%, 17.78$ and $26.36 \%$, 13.55 and $22.51 \%, 24.84$ and $35.72 \%$, and 16.18 and $25.93 \%$ respectively. The $\mathrm{CP}$ contents of leaves from Raphinus radicula and Raphinus sativus were significantly $(\mathrm{P}<0.001)$ higher than the other vegetables. The NDF content of leaves from Beta vulgaris was significantly $(\mathrm{P}<0.001)$ higher than the others. The ADF content of Raphinus sativus was significantly $(\mathrm{P}<0.001)$ higher than the others. The species significantly $(\mathrm{P}<0.001)$ affected the gas production, metabolisable energy and methane production although OMD of vegetable leaves was not significantly $(\mathrm{P}>0.05)$ affected by species. The gas production of vegetable leaves varied between 37.93 and $45.25 \mathrm{ml}$. The gas production of Daucus carota var atrorubens and Apium graveolens were significantly $(\mathrm{P}<0.001)$ higher than the others. The metabolisable energy ranged from 8.90 to $10.16 \mathrm{MJ} / \mathrm{kg}$ DM. The methane production (ml) varied between 6.67 $\mathrm{ml}$ to $11.13 \mathrm{ml}$. The methane production of Beta vulgaris was significantly $(\mathrm{P}<0.001)$ higher than the others. The percentage of methane production ranged from 17.60 to $25.46 \%$. Leaves of vegetables from Daucus carota var atrorubens, Daucus carota, Raphinus radicula, Raphinus sativus, Apium graveolens and Beta vulgaris have a significant potential to provide considerable amount of energy and protein for ruminant animals. However high level of methane production potential of leaves of Beta vulgaris should be taken into consideration when included into ruminant diets.
\end{abstract}

Keywords: Metabolisable energy, in vitro gas production, organic matter digestibility, vegetables leaves

\section{Bazı Sebze Yaprakların Kimyasal Kompozisyonları ve Ruminant Hayvanlar için Besleme Değerinin Belirlenmesi}

ÖZET: Bu çalışma bazı sebze yapraklarının kimyasal kompozisyonunu ve ruminantlar için besleme değerini belirlemek için yürütülmüştür. Sebzenin türü yaprakların kimyasal kompozisyonunu önemli $(\mathrm{P}<0.001)$ derecede etkilemiştir. Sebzelerin kuru madde, ham kül, ham protein, nötral deterjan fiber, asit deterjan fiber içerikleri surasıly $\% 8.29$ ile $20.89, \% 17.78$ ile $26.36, \% 13.55$ ile $22.51, \% 24.84$ ile 35.72 ve $\% 16.18$ ile 25.93 arasında değişmiştir. Kırmızı ve beyaz turp yaprağının ham protein içeri diğer sebzelerin ham protein içeriğinden önemli derecede $(\mathrm{P}<0.001)$ daha yüksek bulunmuştur. Şeker pancarı yapră̆ının nötral deterjan fiber içeriği diğer sebzelerin nötral deterjan fiber içeriğinden önemli derecede $(\mathrm{P}<0.001)$ daha yüksek bulunmuştur. Sebze türü sebzelerin gaz üretimini, metabolik enerji ve metan üretimini önemli derecede $(\mathrm{P}<0.001)$ etkilerken sebzelerin organik madde sindirim derecesini önemli derecede ( $\mathrm{P}>0.05)$ etkilememiştir. Sebzelerin gaz üretimi 37.93 ile $45.25 \mathrm{ml}$ arasında değişmiştir. Siyah havuç ve kereviz yaprağından üretilen gaz miktarı diğer sebzelerden önemli derecede $(\mathrm{P}<0.001)$ daha yüksek bulunmuştur. Sebzelerin metabolik enerji içeriği 8.90 ile $10.16 \mathrm{MJ} / \mathrm{kg}$ arasında değişmiştir. Sebzelerin metan üretimi $6.67 \mathrm{ml}$ ile $11.13 \mathrm{ml}$ arasında değişmiştir. Şeker pancarı yaprağının metan üretimi diğer sebzelerin metan üretiminden daha yüksek bulunmuştur. Metan gazı üretiminin yüzdesel olarak 17.60 ile 25.46 arasında değişmiştir. Siyah havuç, beyaz havuç, kırmızı turp, beyaz turp, kereviz ve şeker pancarı yaprağı ruminant hayvanlara enerji ve protein sağlamada önemli bir potansiyele sahiptir. Bununla birlikte şeker pancarının ruminant hayvanların rasyonlarına katılması durumunda şeker pancarının yüksek miktarda metan üretim potansiyeli göz önüne alınmalıdır.

Anahtar kelimeler: Metabolik enerji, in vitro gaz üretimi, organik madde sindirim derecesi, sebze yaprakları

Kahramanmaraş Sütçü İmam Üniversitesi, Ziraat Fakültesi, Zootekni, Kahrmanmaraş, Türkiye

Iğdır Üniversitesi, Ziraat Fakültesi, Zootekni, Iğdır, Türkiye

Sorumlu yazar/Corresponding Author: Çağrı Özgür ÖZKAN, cagri@ksu.edu.tr 


\section{INTRODUCTION}

Forages are very important components of ruminant diets, which provide energy, protein and minerals. There is a considerable shortage of high quality forage availability in Turkey as in many parts of world.

Therefore the non-conventional feed resources such as byproducts from vegetable farming have been used in ruminant diets to overcome the forage shortages (Karkoodi et al., 2012; Akinfemi, 2012; Azevedo et al., 2012; Ezeldin et al., 2016).

Although every year, considerable amount of vegetable byproducts has been produced in Turkey, the vegetable byproducts have not used effectively in ruminant diets due to lack of information about chemical composition and nutritive value such as metabolisable energy and digestibility. It is well known that the major constraint of inclusion of vegetable by products into ruminant diets is the available information about the vegetable by products.

Therefore the aim of the current experiment was to obtain some information about chemical composition and nutritive value such as metabolisable energy and digestibility using approximate analysis and in vitro gas production technique.

\section{MATERIAL AND METHOD}

After harvesting, the leaves of vegetables from Daucus carota var atrorubens, Daucus carota, Raphinus radicula, Raphinus sativus, Apium graveolens and Beta vulgaris were collected and dried in the laboratory. Dry matter (DM), crude ash (CA), Crude protein contents of leave samples were determined by method of AOAC (1990). Neutral and acid detergent fibers were analyzed by the method of Van Soest et al. (1991).

\section{In vitro gas and methane production}

Approximately 0.200 gram of vegetable leaves were incubated with buffered rumen fluid for $24 \mathrm{~h}$ in a water bath at $39{ }^{\circ} \mathrm{C}$ in triplicate using the methods of Menke et al. (1979). Rumen fluid was obtained from three fistulated sheep fed twice daily with a diet containing alfalfa hay $(60 \%)$ and concentrate (40\%).

Methane contents (\%) of total gas produced at $24 \mathrm{~h}$ fermentation of samples were measured using an infrared methane analyzer (Sensor Europe $\mathrm{GmbH}$, Erkrath, Germany) (Goel et al., 2008).

The metabolisable energy (MJ/kg DM) and OMD of vegetable leaves were estimated with equations of Menke and Steingass (1988) as follows:

$$
\begin{aligned}
& M E(\mathrm{MJ} / \mathrm{kg} \mathrm{DM})=2.20+0.1357 G P+0.057 C P+0.0028597 E E^{2} \\
& O M D(\%)=15.38+0.8453 G P+0.595 C P+0.675 C A
\end{aligned}
$$

Where,

$$
\begin{aligned}
& G P \text { is } 24 \mathrm{~h} \text { net gas production }(\mathrm{ml} / 200 \mathrm{mg}), \\
& C P=\text { Crude protein }(\%) \\
& E E: \text { Ether extract }(\%) \\
& C A: \text { Crude ash }(\%)
\end{aligned}
$$

\section{Statistical analysis}

Data of vegetable leaves were evaluated using oneway analysis of variance. Differences among means were determined with Tukey's multiple range tests.

\section{RESULTS AND DISCUSSION}

The effect of species on the chemical composition of vegetable leaves is given in Table 1 . The species significantly $(\mathrm{P}<0.001)$ affected the chemical composition of vegetables leaves. The DM contents of vegetable leaves varied between 8.29 and $20.89 \%$. The DM contents of leaves from Daucus carota and Beta vulgaris were significantly $(\mathrm{P}<0.001)$ higher than the others. The DM contents of leaves from Raphinus radicula and Raphinus sativus were consistent with the findings of Islam et al. (2004), AbdEl-Fattah (2014) and Wadhwa and Bakshi (2013). The DM contents of 
Daucus carota var atrorubens and Daucus carota were consistent with that reported by Azevedo et al. (2012) but higher than that reported by Wadhwa and Bakshi (2013). The DM content of leave of Beta vulgaris was consistent with that reported by Carter (2015) and Ak and Uzatici, (2011) but higher than that reported by Islam et al. (2004) and Gurbuz and Kaplan (2008). The DM content of Apium graveolens was in agreement with that reported by AbdEl-Fattah (2014) but lower than that reported by Carter (2015).

Some of the differences in DM contents of leaves are likely associated with harvesting stage of vegetables. It is well known that harvesting stage is the most important factor affecting the DM contents of plants. The DM contents of plants increased with advancing maturity (Kamalak 2010; Kamalak et al., 2011).

The CP contents of vegetable leaves varied between 13.55 and $22.51 \%$. Some of the differences in
$\mathrm{CP}$ contents of vegetables leaves are likely associated with harvesting stage of plant. It is well known that harvesting stage is the most important factor affecting the $\mathrm{CP}$ content of plant. The CP content of plants decreased with advancing maturity (Kamalak 2010; Kamalak et al., 2011).

The CP contents of Raphinus radicula and Raphinus sativus were higher than the other vegetables. It seems to be likely that all vegetables leaves studied in the current experiment will meet the $\mathrm{CP}$ requirements of ewes for maintenance and lactation since the $\mathrm{CP}$ content of vegetables leaves studied in this experiment higher than those requested for maintenance and lactation of sheep.

El-Shatnawi and Mohawesh (2000) indicated that the level of CP for ewes at maintenance and lactation should be higher than $7-9 \%$ and $10-12 \%$ respectively.

Table 1. The effect of species on the chemical composition of vegetable leaves

\begin{tabular}{|l|c|c|c|c|c|c|}
\hline Vegetable Species & DM & CA & CP & NDF & ADF & EE \\
\hline $\begin{array}{l}\text { Daucus carota var } \\
\text { atrorubens }\end{array}$ & $19.38^{\mathrm{b}}$ & $21.93^{\mathrm{ab}}$ & $13.55^{\mathrm{f}}$ & $27.58^{\mathrm{bc}}$ & $24.88^{\mathrm{ab}}$ & $6.17^{\mathrm{c}}$ \\
\hline Daucus carota & $20.89^{\mathrm{a}}$ & $24.19^{\mathrm{ab}}$ & $18.36^{\mathrm{d}}$ & $28.21^{\mathrm{b}}$ & $21.95^{\mathrm{bc}}$ & $5.14^{\mathrm{c}}$ \\
\hline Raphinus radicula & $8.29^{\mathrm{d}}$ & $26.36^{\mathrm{a}}$ & $20.87^{\mathrm{b}}$ & $24.84^{\mathrm{c}}$ & $22.91^{\mathrm{abc}}$ & $19.79^{\mathrm{a}}$ \\
\hline Raphinus sativus & $9.14^{\mathrm{d}}$ & $22.95^{\mathrm{ab}}$ & $22.51^{\mathrm{a}}$ & $27.78^{\mathrm{b}}$ & $25.93^{\mathrm{a}}$ & $13.55^{\mathrm{b}}$ \\
\hline Apium graveolens & $10.92^{\mathrm{c}}$ & $17.78^{\mathrm{b}}$ & $19.46^{\mathrm{c}}$ & $29.57^{\mathrm{b}}$ & $19.95^{\mathrm{c}}$ & $15.74^{\mathrm{b}}$ \\
\hline Beta vulgaris & $20.45^{\mathrm{ab}}$ & $19.42^{\mathrm{b}}$ & $17.30^{\mathrm{e}}$ & $35.72^{\mathrm{a}}$ & $16.18^{\mathrm{d}}$ & $18.02^{\mathrm{a}}$ \\
\hline \multicolumn{1}{|c|}{ SEM } & 0.436 & 2.014 & 0.164 & 0.841 & 0.900 & 0.654 \\
\hline \multicolumn{1}{|c|}{ Sig } & $* * *$ & $* * *$ & $* * *$ & $* * *$ & $* * *$ & $* * *$ \\
\hline
\end{tabular}

${ }^{\text {abc }}$ Column means with common superscripts do not differ $(\mathrm{P}<0.05)$; S.E.M. - standard error mean; Sig. - significance level; DM - Dry matter \%, CA: crude ash $\%, \mathrm{CP}$ - Crude protein $\%, \mathrm{NDF}-$ Neutral detergent fiber \%, ADF - Acid detergent fiber\%, EE: Ether extract (\%), ${ }^{* * *} \mathrm{P}<0.001$

The CA contents of vegetable leaves varied between 17.78 and $26.36 \%$. The CA contents of Daucus carota var atrorubens and Daucus carota were in agreement with that reported by Ezeldin et al. (2016). The CA content of Raphinus radicula and Raphinus sativus were consistent with those reported by Wadhwa and Bakshi (2013). The CA content of Beta vulgaris was in agreement with that reported by
Gurbuz and Kaplan (2008) and Wadhwa and Bakshi (2013) but lower than that Ezeldin et al. (2016). Some of the differences in CA contents of leaves are likely associated with harvesting stage of plants. It is well known that harvesting stage is the most important factor affecting the CA contents of plants. The CA content of plants decreased with advancing maturity (Kamalak 2010; Kamalak et al., 2011). 
The NDF contents of vegetable leaves varied between 24.84 and $35.72 \%$. The NDF content of Beta vulgaris was significantly $(\mathrm{P}<0.001)$ higher than the others. The NDF content of Apium graveolens was consistent with that reported by Carter (2015) but higher than that reported by Marino et al. (2010). The NDF content of Raphinus radicula was in agreement with that reported by Wadhwa and Bakshi (2013) but lower than that reported by Islam et al. (2004). The NDF contents of Daucus carota var atrorubens and Daucus carota were significantly lower than that reported by Islam et al. (2004). The NDF content of Beta vulgaris is higher than that reported by Carter (2015). Some of the differences in NDF contents of leaves are likely associated with harvesting stage of plant. It is well known that harvesting stage is the most important factor affecting the NDF contents of plants. The NDF content of plants increased with advancing maturity (Kamalak 2010; Kamalak et al., 2011).

The ADF contents of vegetable leaves varied between 16.18 and $25.93 \%$. The ADF content of Raphinus sativus was significantly $(\mathrm{P}<0.001)$ higher than the others. Daucus carota, Apium graveolens and
Beta vulgaris. The ADF contents of Daucus carota var atrorubens and Daucus carota were lower than that reported by Azevedo et al. (2012). The ADF contents of Raphinus radicula and Raphinus sativus was in agreement with those reported by Wadhwa and Bakshi (2013) and AbdEl-Fattah (2014). The ADF content of Beta vulgaris was lower than that reported by Wadhwa and Bakshi (2013). Some of the differences in ADF contents of leaves are likely associated with harvesting stage of plant. It is well known that harvesting stage is the most important factor affecting the NDF contents of plants. The ADF content increased with advancing maturity (Kamalak 2010; Kamalak et al., 2011; Kaplan et al. 2014).

The EE contents of vegetable leaves varied between 5.14 and $19.79 \%$. The EE contents of Raphinus radicula and Beta vulgaris were significantly higher than the others.

The effect of species on the gas production, metabolisable energy and organic matter digestibility of vegetables is given in Table 2 . The species significantly affected on all these parameters except for organic matter digestibility of vegetable leaves.

Table 2. The effect of species on gas production, metabolisable energy, organic matter digestibility and methane production of vegetable leaves

\begin{tabular}{|l|c|c|c|c|c|}
\hline Vegetable Species & GP & ME & OMD & $\mathbf{C H}_{4}(\mathbf{m l})$ & $\mathbf{C H}_{4}$ \% \\
\hline Daucus carota var atrorubens & $44.96^{\mathrm{a}}$ & $9.18^{\mathrm{b}}$ & 76.26 & $8.08^{\mathrm{c}}$ & $17.97^{\mathrm{c}}$ \\
\hline Daucus carota & $41.10^{\mathrm{bc}}$ & $8.90^{\mathrm{c}}$ & 77.38 & $7.50^{\mathrm{d}}$ & $18.26^{\mathrm{c}}$ \\
\hline Raphinus radicula & $40.29^{\mathrm{cd}}$ & $9.98^{\mathrm{a}}$ & 76.66 & $7.15^{\mathrm{de}}$ & $17.75^{\mathrm{c}}$ \\
\hline Raphinus sativus & $37.93^{\mathrm{d}}$ & $9.16^{\mathrm{b}}$ & 76.33 & $6.67^{\mathrm{e}}$ & $17.60^{\mathrm{c}}$ \\
\hline Apium graveolens & $45.25^{\mathrm{a}}$ & $10.16^{\mathrm{a}}$ & 77.20 & $9.10^{\mathrm{b}}$ & $20.11^{\mathrm{b}}$ \\
\hline Beta vulgaris & $43.71^{\mathrm{ab}}$ & $10.05^{\mathrm{a}}$ & 75.74 & $11.13^{\mathrm{a}}$ & $25.46^{\mathrm{a}}$ \\
\hline \multicolumn{1}{|c|}{ SEM } & 0.901 & 0.056 & 1.416 & 0.901 & 0.284 \\
\hline Sig. & $* * *$ & $* * *$ & $\mathrm{NS}$ & $* * *$ & $* * *$ \\
\hline
\end{tabular}

a bc Column means with common superscripts do not differ $(\mathrm{P}<0.05)$; S.E.M. - standard error mean; $\quad$ Sig. - significance level; NS: Not significant, GP: Gas production (ml), ME: Metabolisable energy (MJ / kg DM), OMD: Organic matter digestibility (\%), CH4 - Methane emission(ml or \%), , ***P<0.001

The gas production of vegetable leaves varied between 37.93 and $45.25 \mathrm{ml}$. The gas production of Daucus carota var atrorubens and Apium graveolens were higher than the others. The GP of Beta vulgaris, Raphinus radicula and Raphinus sativus were significantly higher than that reported by Wadhwa 
and Bakshi (2013). Some of the differences in GP contents of leaves are likely associated with differences in chemical composition of plant fermented. Gas production produced during the fermentation decreased with decrease in the availability of fermentable substrate with advancing maturity (Kamalak 2010; Kamalak et al., 2011).

The ME contents of vegetable leaves varied between 8.90 to $10.16 \mathrm{MJ} / \mathrm{kg}$ DM. The ME contents of Raphinus radicula, Apium graveolens and Beta vulgaris were significantly $(\mathrm{P}<0.001)$ higher than the other vegetables. The ME contents of Raphinus radicula, Raphinus sativus and Beta vulgaris were higher than that reported by Wadhwa and Bakshi (2013). On the other hand the ME contents of Raphinus radicula, Raphinus sativus and Beta vulgaris were lower than that reported by Wadhwa and Bakshi (2013). The ME content of Apium graveolens was higher than that reported by Marino et al. (2010) whereas the OMD of Apium graveolens was lower than that reported by Marino et al. (2010).

The methane production $(\mathrm{ml})$ of vegetables leaves varied between $6.67 \mathrm{ml}$ to $11.13 \mathrm{ml}$. The methane production of Beta vulgaris was significantly higher than the others. The percentage of methane ranged

\section{REFERENCES}

AbdEl-Fattah SA, 2014. Biochemical and nutritional impact of celery and turnip leaves on induced obese by high fat diet (HFD). Journal of Food and Nutrition Sciences, 2(6):285-302.

Ak I, Uzatici A, 2001. Şeker pancarı yapraklarının hayvan beslemede kullanımı. Atatürk Üniversitesi Ziraat Fakültesi Dergisi, 32(1):95-99.

Akinfemi A, 2012. Evaluation of nutritive value of vegetable wastes grown in North Central Nigeria using in vitro gas production technique in ruminant Animals. Journal of Animal Science Advances, 2(11):914-920.

AOAC, 1990. Official method of analysis. $15^{\text {th }}$ ed., pp.66-88. Association of official analytical chemists, Washington, DC, USA.

Azevedo JAG, Filho SCV, Pina DS Detman E, Pereira LGR, Valadares RFD, Fernandes HJ, Silva LFC, Beneden PB, 2012. Nutritional diversity of agriculture and agro-industrial by-products for ruminant feeding. Arquivo Brasileiro de Medicina Veterinária e Zootecnia, 64(5):1246-1255.

Carter NA, 2015. Enhancing pig productivity on East African Smallholder farms. PhD Thesis, Guelph, Ontario, Canada. pp.131-132. from 17.60 to $25.46 \%$. The percentage of methane of gas produced range from 16 to $20 \%$ when the usual feeds such as forage, concentrate and their mixtures are subjected to in vitro fermentation for $24 \mathrm{~h}$ (Lopez et al. 2010). Therefore it is very interesting to notice that percentage of methane of all leaves fell into similar range between 17.97 and $20.11 \%$ whereas the percentage of methane from Beta vulgaris was significantly higher than the others. It is likely that the inclusion of leaves of Beta vulgaris into ruminant diets will result in increase in enteric methane emission which is not desirable for energy efficiency and environmental aspects. Therefore care must be taken when leaves of Beta vulgaris is included into ruminant diets.

\section{CONCLUSION}

Leaves of vegetables from Daucus carota var atrorubens, Daucus carota, Raphinus radicula, Raphinus sativus, Apium graveolens and Beta vulgaris have a potential to provide considerable amount of energy and protein for ruminant animals. However high level of methane production potential of leaves of Beta vulgaris should be taken into consideration when included into ruminant diets.
El-Shatnawi MK, Mohawesh YM, 2000. Seasonal chemical composition of saltbush in semiarid grassland of Jordan. Journal of Range Management, 53: 211-214.

Ezeldin I, Elbashier OM, Omer AS, 2016. Evaluation of some vegetable wastes as feedstuff for ruminants. International Journal of Science and Research, 5(3):628-631.

Goel G, Makkar HPS, Becker K, 2008. Effect of Sesbania sesban and Carduus pycnocephalus leaves and Fenugreek (Trigonella foenum-graecum L) seeds and their extract on partitioning of nutrients from roughage-and concentrate-based feeds to methane. Animal Feed Science and Technology, 147(1-3): 72-89.

Gurbuz Y, Kaplan M, 2008. Chemical composition, organic matter digestibility, in vitro gas production characteristics and ensiling of sugar beet leaves as alternative feed resource. Journal of Animal and Veterinary Advances, 7 (12): 1568-1574.

Islam MR, Paul DK, Shaha RK, 2004. Nutritional importance of some leafy vegetables available in Bangladesh. Pakistan Journal of Biological Sciences, 7(8):1380-1384.

Kamalak A, 2010. Determination of potential nutritive value of Polygonum aviculare hay harvested at three maturity stages. Journal of Applied Animal Research, 38: 69-71. 
Kamalak A, Atalay AI, Ozkan CO, Kaya E, Tatliyer A, 2011. Determination of potential nutritive value of Trigonella kotschi fenzl hay harvested at three different maturity stages. Journal of Veterinary Faculty, Kafkas University, 17 (4): 635640.

Kaplan M, Kamalak A, Kasra AA, Güven I, 2014. Effect of maturity stages on potential nutritive value, methane production and condensed tannin content of Sanguisorba minor hay. Journal of Veterinary Faculty, Kafkas University, 20: 445-449.

Karkoodi K, Fazaeli H, Mirghaffari SS, 2012. Assessing the nutritive value of fruit and vegetable residues as ruminant feed. Turkish Journal of Veterinary and Animal Science, 36(3):239-244.

Lopez S, Makkar HPS, Soliva CR, 2010. Screening plants and plant products for methane inhibitors. In, Vercoe PE, Makkar HPS, Schlink A (Eds): In vitro Screening of Plant Resources for Extra-nutritional Attributes in Ruminants: Nuclear and Related Methodologies. pp.191-231, London, New York.
Marino CT, Rodrigues PHM, Borgati LMO, Meyer M, Silva EJA, Orskov ER, 2010. Characterization of vegetables and fruits potential as ruminant feed by in vitro gas production technique. Livestock Research for Rural Development. Volume 22, Article \#168.Retrieved December 2, 2016, from http://www. lrrd.org/lrrd22/9/mari22168.htm

Menke KH, Raab L, Salewski A, Steingass H, Fritz D, Schneider W, 1979. The estimation of the digestibility and metabolizable energy content of ruminant feedingstuffs from the gas production when they are incubated with rumen liquor in vitro. Journal of Agricultural Science (Camb) 93:217-222.

Menke KH, Steingass H, 1988. Estimation of the energetic feed value obtained from chemical analysis and in vitro gas production using rumen fluid. Animal Research Development, 28:7-55.

Wadhwa M, Bakshi MPS, 2013. Utilization of fruit and vegetable wastes as livestock feed and as substrates for generation of other value-added products. RAP Publication2013/04. pp.1-57. 